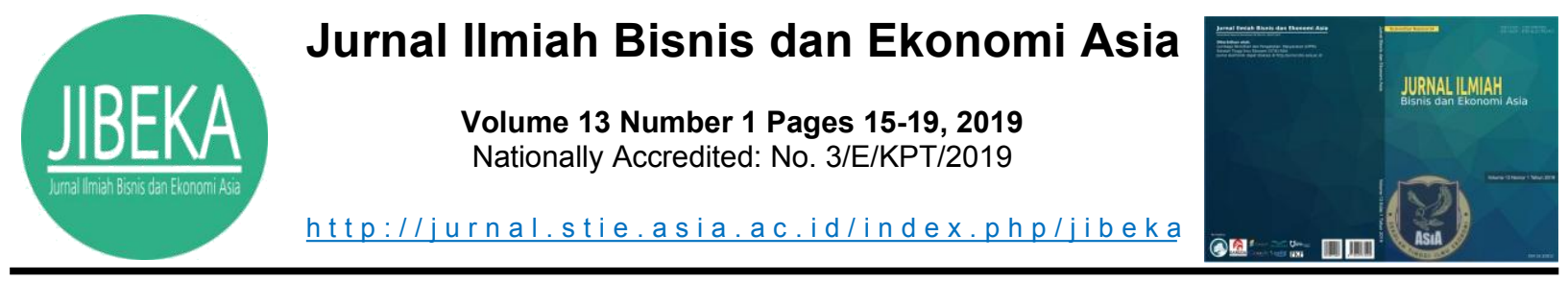

\title{
WANITA DAN PERANANNYA DALAM MEMAJUKAN UMKM BATIK DI KEBUMEN
}

\author{
Siti Nur Azizah* \\ Sekolah Tinggi Ilmu Ekonomi Putra Bangsa, Indonesia
}

INFO ARTIKEL

DOI: $10.32812 /$ jibeka.v13i1.98

ISSN-P: 0126-1258

ISSN-E: 2620-875X

Keywords: Women, Batik, SMES

\begin{abstract}
The role of women in SMEs in Kebumen is still 20-30 percent based on data from the Department of Industry and Cooperatives of Kebumen Regency. Increasing family welfare through women's participation which indirectly influences development in general is the reason behind this research. There needs to be efforts related to empowering women to function as subjects and objects of development, both individually, family members and citizens. This study aims to analyze, describe and interpret what factors influence women's empowerment so that it can improve the family's economic welfare. This study is a descriptive study using structured interviews. Subjects were 30 female batik entrepreneurs in Pejagoan and Alian Districts. The results show both women entrepreneurs run businesses to help the family economy and still have little business knowledge, so the local government still has to provide assistance for the progress of the batik industry, especially those owned by women.
\end{abstract}

\section{ABSTRAK}

Peranan wanita dalam UMKIM di Kebumen masih 20-30 persen

Kata Kunci: Wanita, Batik, UMKM Kabupaten Kebumen. Meningkatnya kesejahteraan keluarga melaui peranan wanita dimana secara tidak langsung mempengaruhi perkembangan secara umum adalah menjadi alasan utama dari penelitian ini. Ada suatu kebutuhan menjadi usaha yang berkaitan dengan memberdayakan wanita sebagai fungsi dari subyek dan obyek dari pengembangan, baaik secara individu, anggota keluarga maupun bagian dari masyarakat. Tujuan dari studi ini adalah untuk menganalisa, menggabarkan dan mengintepretasikan faktor-faktor apa saja yang mempengaruhi pemberdayaan wanita sehingga dapat meningkatkan kesejahteraan ekonomi keluarga. Studi ini adalah studi desktriptif menggunakan wawancara terstruktur. Subyek adalah 30 pengusaha batik wanita di daerah Pejagon dan Alian. Hasil penelitian menunjukkan bahwa pengusaha wanita yang menjalankan bisnis untuk membantu ekonomi keluarga dan masih memiliki pengetahuan bisnis yang sedikit, jadi pemerintah setempat tetap harus memberikan bantuan untuk keberlangsungan dari industri batik, terutamnya yang dimiliki oleh wanita. 


\section{Pendahuluan}

Keberadaan usaha kecil dan menengah mempunyai peranan penting bagi perekonomian dalam negeri, terlebih kekokohan sektor UKM terbuki mampu bertahan ditengah krisis ekonomi 1998. Karena bagaimapun juga masih positifnya pertumbuhan ekonomi Indonesia tidak bisa lepas ditopang dari sektor UKM. Bahkan, UKM milik perempuan pun tidak mau kalah ikut serta dalam kontribusinya kepada ekonomi nasional. Berdasarkan data Kementerian Koperasi dan UKM Republik Indonesia pada 2010 sekitar $60 \%$ UKM dikelola oleh perempuan Indonesia. Dimungkinkan peranannya semakin meningkat. Hal ini menunjukkan perempuan memiliki peranan penting dalam meningkatkan perekonomian negara.

Sebagaimana di negara lain, kepemilikan wanita Indonesia adalah pada usaha kecil. Dalam menerapkan definisi nasional UKM, survei Bank Dunia tahun 2016 menjumpai bahwa $52,9 \%$ usaha mikro, 50,6\% usaha kecil dan 34,0\% usaha menengah di daerah perkotaan dimiliki oleh wanita. Kedudukan dan peran wanita dalam memajukan perekonomian keluarga memiliki beberapa indikator yang dapat menjadi tolok ukur, diantaranya adalah dengan mengalisa kegiatan-kegiatan yang dilakukan wanita pelaku UMKM pada umumnya dalam masyarakat, berupa kegiatan usaha, jenis pelakuan, dan status pelakuan. Indikator tersebut akan diperoleh gambaran mengenai kegiatan produktif seperti apakah yang dapat menghasilkan upah atau imbalan yang sesuai dengan kegiatan wanita pelaku UMKM tesebut, bagaimana proporsi wanita dalam bekerja, status wanita dalam pelakuan di industri UMKM, posisi wanita pekerja apakah sudah sesuai atau tidak. Kajian tentang wanita di lapangan dapat dihubungkan dengan keadaan masyarakat yang pada umumnya dipengaruhi oleh kebutuhan disamping nilai-nilai yang berlaku dalam masyarakat. kegiatankegiatan yang dilakukan oleh wanita apakah sudah sewajarnya tidak langsung berkaitan dengan urusan rumah tangga, juga menentukan perannya.

Kabupaten Kebumen merupakan salah satu sentra batik yang berpusat di beberapa kecamatan antara lain Pejagoan, Alian dan sebagian kecil kecamatan Adimulyo sebagai sentra yang baru dikembangkan. Berdasarkan pengamatan usaha ini rata-rata dimiliki wanita sebagai pekerjaan sambilan. Hasilnya disetorkan kepada pengepul dan baru sedikit yang mampu mengelola pemasarannya secara mandiri. Kemampuan manajerial dan modal merupakan permasalahan klasik UMKM padahal usaha ini menopang ekonomi keluarga.

Dalam Bedasarkan data Departemen Perdagangan dan Perindustrian peran wanita di UMKM adalah 60 persen (2013) dan dimungkinkan terus meningkat (Alamsyah, 2017). Namun pada kenyataanya hal tersebut belum terjadi pada UMKM Kebumen, berdasarkan data Dinas Perindustrian dan Koperasi (2013) peran wanita pada UMKM di Kebumen peranan wanita baru 20 sampai 30 persen. Apa sajakah yang menjadi kendala para pengrajin batik wanita dalam berusaha? Peranan tersebut masih bisa ditingkatkan lagi dengan berbagai kebijakan. Kebijakan seperti apakah kebijakan yang pro gender?

UMKM di Indonesia memiliki definisi terkait kriteria dalam hal permodalan dan omzet. UMKM menurut Undang - Undang No. 20 Tahun 2008 terdiri dari usaha mikro dengan kekayaan maksimal lima puluh juta rupiah, usaha kecil dengan maksimal kekayaan lima atus juta rupaih dan usaha menengah dengan kekayaan maksimal sepuluh milyar rupiah (Undang-Undang Republik Indonesia Nomor 20 Tahun 2008 Tentang Usaha Mikro, Kecil, Dan Menengah, 2008).

Sejak terjadinya krisis ekonomi 1997 makin banyak perhatian dari semua pihak bagi perempuan dalam mengembangkan usahanya, terutama di UMKM sebagai tempat pengembangan kemampuan kewirausahaan wanita. Data dari hasil survei tenaga kerja nasional: perkembangan wirausaha wanita dipengaruhi oleh banyak faktor, yang sebagian bersifat langsung dan bersifat tidak langsung. Tekanan ekononomi, sosial dan budaya menjadi determinan langsung. Faktor tidak langsung adalah kebijakan pemerintahan dan stabilitasi lingkungan sosial ekonomi domestik. 


\section{Metode Penelitian}

Penelitian ini menggunakan metode statistik deskriptif dilakukan dengan menyebarkan 30 kuesioner secara acak pada 30 sampel responden pengrajin batik wanita di Kecamatan Alian dan Pejagoan, Kebumen. 20 responden dari Pejagoan dan 10 responden dari Alian. Tujuannya untuk mengetahui kendala internal pengembangan usaha mereka. Di Kebumen terdapat 216 pengrajin batik (Data Perindagkop, 2014) dibawah bimbingan dinas koperasi.

Usia responden rata rata $40-50$ tahun mendominasi pengrajin $(90 \%)$ hanya $10 \%$ berusia muda 25-39 th. Pendidikan rata-rata SD dan SMP (80\%) sisanya SLTA (20\%). Hal ini menunjukkan usaha ini jarang diminati usia muda dan berpendidikan karena dianggap tidak menjanjikan. Berdasarkan data deskriptif diketahui rata-rata pengasilan perbulan $>\mathrm{Rp}$. 1.000.000,- sebanyak 6 responden (23\%), Rp. 1.000.001 - 3.000.000,- sebanyak 21 responden (70\%) sisanya 3 responden diatas Rp. 3.000.000,- Rp 5000.000,- (10\%).

\section{III.Hasil Penelitian dan Pembahasan}

Berdasarkan self assessment (penilaian diri sendiri) yang didasarkan pada kuisioner yang disebar kepada pengrajin batik wanita di Alian dan Pejagoan pada 30 orang membuktikan jika ada beberapa kendala internal yang membuat para pekerja wanita masih bimbang untuk mengembangkan potensi sebagai seorang wirausaha. Faktor utama (jawaban alasan nomor satu) yang menjadi kendala adalah:

1. Mengambil keputusan dengan banyak pertimbangan sebanyak lima belas orang $(50 \%)$ Wanita dikenal dengan sikapnya yang mengedepankan emosi dibandingkan dengan logika ketika mengerjakan sebuah pekerjaan. Hal ini merupakan salah satu faktor dimana perempuan cukup lama dalam mengambil sebuah keputusan yang mana hal tersebut dipengaruhi oleh emosi. Bahkan tidak jarang mereka mengambil keputusan dimana keputusan tersebut didasarkan oleh emosi mereka dan tidak memikirkan efek atau hasil akhir yang akan didapat di kemudian hari.

2. Pengetahuan wirausaha yang kurang sebanyak tujuh orang $(23 \%)$

Para pekerja wanita selain mereka memiliki kewajiban untuk bekerja, mereka juga memiliki kewajiban untuk mengurus rumah tangga. Maka hal ini menjadikan wanita harus memiliki waktu ekstra 2 (dua) kali lipat lebih sibuk dibandingkan laki. Hal inilah yang menjadikan mereka tidak memiliki waktu untuk belajar hal baru yang sebetulnya dapat menjadikan mereka lebih berkembang baik secara pengetahuan dan keahlian.

3. Takut gagal sebanyak lima orang $(17 \%)$

Pekerja wanita terkenal ulet dalam bekerja, namun disisi lain wanita cenderung takut akan gagal sehingga tidak jarang wanita ragu-ragu untuk terjun dalam dunia pekerjaan yang menuntutnya harus selalu mencoba hal yang baru. Dan yang sering terjadi adalah pekerja wanita lebih banyak memilih untuk bekerja pada sektor yang dia rasa merupakan passionnya. Sehingga tidak jarang pula para pekerja wanita ini lebih milih untuk stagnan pada posisinya sebagai karyawan sekarang dari pada memilih untuk naik jabatan atau pun beralih pada pekerjaan yang baru.

4. Memiliki Empati yang terlalu tinggi sebanyak tiga (10\%)

Wanita dikenal memiliki empati yang tinggi. Empati merupakan rasa simpati berlebih terhadap keadaan sekitar dan seakan- akan turut merasakan. Kondisi tersebut bukanlah hal yang dilarang namun jika pada dunia usaha maka hal tersebut dapat menjadi boomerang bagi wanita itu sendiri. Dalam dunia usaha, rasa empati merupakan kendala yang dapat menghambat perkembangan bisnis dan karir pekerja wanita. Sebab tidak jarang wanita yang mengandalkan empatinya bersikap kurang tegas terhadap kebijakan yang seharusnya dia terapkan. 


\section{Tingkat Kinerja Pemilik Bisnis UKM Perempuan}

Hasil survey pada 30 pengrajin batik wanita di Alian dan Pekagoan dengan kuisioner mendapatkan hasil (Japhta, Murthy, Fahmi, Marina, \& Gupta, 2016):

a. Faktor pendorong wanita dalam pengembangan UKM

Pertanyaan apa yang mendorong wanita pembatik di Alian dan Pejagoan atau memotivasi wanita melakukan usaha, yaitu untuk menentukan apa yang ingin dicapai, tujuan apa yang hendak dicapai, serta produk apa yang akan dihasilkan. Dari hasil penelitian 93\% (27 Orang) menyatakan ingin meringankan beban keluarga, mengubah nasib 1 orang (3\%), ingin mencptakan lapangan pekerjaan 2 orang (4\%). Banyaknya motivasi wanita melakukan usaha karena ingin mengurangi beban keluarga menunjukkan adanya kesadaran dari wanita atas kondisi pengangguran yang semakin meningkat, adanya kesadaran dari wanita untuk menciptakan pekerjaan bukan mencari pekerjaan.

b. Hubungan Kerja Antara Pelaku Usaha Dengan Bawahan dan Mitra Usaha

Dilihat dari hubungan kerja pimpinan/pelaku usaha dengan anak buah/staf/manajer atau dengan sejawat seluruhnya menyatakan tidak ada kesulitan. Dalam hal hubungan dengan mitra usaha, dalam penelitian ini ternyata dari 20 responden yang menyatakan tidak ada kendala sedang yang ada kendala 10 responden $(33,4 \%)$. Kendala hubungan dengan mitra usaha kebanyakan yang banyak diperlukan adalah kemitraan pembayaran tidak tepat waktu, kesulitan dalam penagihan cicilan dan lain sebagainya.

Mulyanto (2006) menjelaskan bahwa gender dan kegiatan usaha seringkali tidak bisa diabaikan keterkaitannya (Mulyanto, 2006). Beberapa jenis usaha sangat beraroma gender. Menurut Tambunan (2002) perempuan di UKM bekerja lebih keras dengan jam kerja yang lebih panjang dibandingkan rekan laki-laki mereka namun di pihak lain, perempuan sering juga dianggap kurang berani mengambil resiko, sehingga implikasinya adalah bahwa usaha-usaha yang dipimpin oleh perempuan bersifat kurang dinamik (Tambunan, 2002). Subanar (2001) berpendapat peran sang entrepreneur atau wirausaha sangat mendominasi perilaku bisnis dan sangat menentukan arah masa depan bagi suatu usaha kecil dan menengah (Subanar, 2001). Nilai-nilai pribadi yang terkait dengan strategi proaktif, sering disebut sebagai nilai-nilai kewirausahaan (Gundry \& Kickul, 2006; Kuratko \& Hodgetts, 1995). Menurut Blackman (2003) mengemukakan dalam literatur menunjukkan bahwa pemilik-manajer dengan nilai-nilai kewirausahaan yang mengadopsi strategi proaktif menunjukkan kinerja lebih kuat/baik dari pada mereka yang kurang nilai-nilai kewirausahaan dengan orientasi strategi reaktif (Blackman, 2003).

Peran perempuan dalam kegiatan UKM dapat dikatakan belum berpartisipasi secara aktif. Menurut daftar perusahaan UKM yang terdaftar pada dinas Perindustrian Perdagangan \& Koperasi (Perindagkop, 2013) Kabupaten Kebumen, porsi peran perempuan dalam pengelolaan dan kepemilikan UKM hanya sebesar $20 \%$. Sedangkan sisanya $80 \%$ dimiliki dan dikelola oleh laki-laki dari total UKM yang terdaftar sebanyak 243 unit usaha. Dengan kata lain, potensi perempuan dalam melakukan perannya sebagai wirausaha di Kabupaten Kebumen belum signifikan.

Alasan perempuan melakukan kegiatan bisnis lebih karena masih sebatas tanggung jawab pada kebutuhan keluarga. Motivasi perempuan dalam melakukan kegiatan bisnis lebih merupakan tekanan untuk menopang kebutuhan keluarga (Sutini dan Suderajat, 2010) dalam Mujib (2011) (Mujib, 2011). Terdapat pula kendala internal, yakni pola pikir perempuan itu sendiri tentang perspektif perempuan memandang dirinya sendiri. Sebagaimana diketahui ada begitu banyak perempuan berpotensi, tetapi tidak semua berani dan percaya diri (Republika.co.id)

Dinas Keluarga Berencana dan Pemberdayaan Masyarakat (KBPM) sebagai mitra dinas Disperindagkop Kabupaten Kebumen dalam menjalankan program pemberdayaan perempuan di sektor UKM bahwa salah satu masalah dalam agenda pembangunan, penanggulangan kemiskinan, dan kesejahteraan sosial adalah ketidaksetaraan dan keadilan gender. Laki-laki dan perempuan memiliki pengalaman kemiskinan yang berbeda. Dampak 
yang diakibatkan oleh kemiskinan terhadap kehidupan laki-laki juga berbeda dengan perempuan. Sumber dari permasalahan kemiskinan perempuan terletak pada budaya patriarki yang bekerja melalui pendekatan, metodologi dan paradigma pembangunan. Sistem kebijakan pemerintahan sebaiknya tidak meminggirkan perempuan melalui kebijakan, program dam lembaga yang tidak responsif gender. Kondisi kesetaraan gender di negara ini masih membutuhkan kerja keras dan menuntut sinergitas segenap komponen pembangunan bangsa, terlebih banyak pemahaman masyarakat yang kurang tepat tentang keadilan gender itu sendiri, termasuk masih terdapatnya perbedaan antara pengusaha perempuan dan pengusaha laki-laki, yang di tentukan terutama oleh budaya dan aspek yang menyantuh seperti penilaian sosial atau masyarakat umum terhadap perempuan karir, beban rangkap sebagai ibu rumah tangga dan pelaku bisnis dan keterbatasan mobilitas, dimana mengakibatkan perempuan seringkali terhambat oleh struktur sosial dalam penciptaan dan pengelolaan bisnis atau koperasi dan UKM

\section{Kesimpulan}

Pada saat ini UKM masih menghadapi permasalahan-permasalahan dalam mengembangkan usahanya, seperti kurang modal, lemahnya sumber daya manusia kurang menguasai teknologi/pasar memperngaruhi kinerja usaha, sehingga permasalahan-permasalahan tersebut perlu dicarikan pemecahan secara terpadu. Adanya kesadaran dan kemauan yang tinggi dari wanita pelaku usaha untuk meningkatkan kemampuan ketrampilannya agar dapat meningkatkan usahanya, baik dalam bentuk pendidikan/pelatihan, studi banding, maupun magang akan mampu meningkatkan peran wanita dalam bisnis sehingga meningkatkan derajat hidup.

\section{Daftar Pustaka}

Alamsyah, I. E. (2017). Peran Perempuan di UMKM Perlu Ditingkatkan. Retrieved from Republika website: https://perma.cc/SAS4-PTQA

Blackman, A. J. (2003). Entrepreneurs: Interrelationship between their characteristics, values, expectations, management practices and performance. Queensland: Griffith University.

Gundry, L. K., \& Kickul, J. R. (2006). Entrepreneurship Strategy: Changing Patterns in New Venture Creation, Growth and Reinvention. Sage Publications.

Japhta, R., Murthy, P., Fahmi, Y., Marina, A., \& Gupta, A. (2016). UKM yang dimiliki Wanita di Indonesia: Kesempatan Emas untuk Institusi Keuangan Lokal.

Kuratko, D. F., \& Hodgetts, R. M. (1995). Entrepreneurship: A Contemporary Approach. Dryden Press.

Mujib, M. F. (2011). Analisis Faktor-Faktor Yang Berpengaruh Secara Langsung dan Tidak Langsung Terhadap Kinerja. Universitas Diponegoro.

Mulyanto, T. (2006). Penguasa Perempuan, Pembangunan dan Tantangan. Yogyakarta: Pustaka Pelajar.

Subanar, R. (2001). Manajemen Usaha Kecil (Empat). Yogyakarta: BPFE Yogyakarta.

Tambunan, T. (2002). Usaha Kecil dan Menengah di Indonesia: Beberapa Isu Penting. Salemba Empat.

Undang-Undang Republik Indonesia Nomor 20 Tahun 2008 Tentang Usaha Mikro, Kecil, Dan Menengah. , Pub. L. No. 20 (2008). 